\title{
LA PINTURA MURAL HISPANO-MUSULMANA. ¿TRADICIÓN O INNOVACIÓN?
}

\author{
CARMEN RALLO GRUSS
}

Universidad Complutense

\section{Introducción}

Tradicionalmente, de acuerdo con lo difundido por Cennini ${ }^{1}$, se dice que la técnica de pintura mural del «buon fresco», trabajada por los romanos, se perdió en el conocimiento de los pintores medievales para ser recobrada por Giotto. También se afirma que Gaspar Becerra fue el «reintroductor» de esta técnica en Castilla, o, según Pacheco, Luis de Vargas en Sevilla ${ }^{2}$. Ese convencimiento de que a finales de la Edad Media las paredes eran decoradas con pintura al seco, realizada con temple, más o menos graso ${ }^{3}$, viene avalado por

\footnotetext{
${ }^{1}$ Cennini C., Tratado de la Pintura (1437), Barcelona, 4. ${ }^{a}$ ed. 1979, 18: «...Y Giotto mudó el arte de pintar de lo griego (gótico) a lo latino, y lo redujo a lo moderno (renacimiento)...», 56 y ss.: "Capítulo LXVII. De qué modo se pinta en el muro, o sea al fresco... Pero tú sigue este método que te diré, que era el usado por el Giotto, gran maestro de la pintura.» Igualmente Vasari, G, «La pintura», Vidas de artistas ilustres (1557), versión de Blázquez, A., Barcelona, 1957, Cap. V, 62, 107: «De los antiguos fue muy usado el fresco, a quien después han seguido los viejos modernos...».

2 Pacheco, A., Arte de la pintura (1649), Barcelona, 1982, 108: «Manejaron este género de pintura (el fresco), en nuestros días, con gran destreza y satisfacción... pero a ninguno debe nada en el tratado de los colores nuestro sevillano Luis de Vargas, como lo mostró en el Arco del Sagrario, torre y Cristo de las gradas a él debemos ser el primero que la trajo a Sevilla, y la primera demostración hizo el año de 1555. Es una imagen del Rosario...».

3 Investigaciones recientes nos cuestionan la «invención» del óleo por los hermanos Van Eyck en el s. XV. Su utilización, introduciéndose cada vez con mayor frecuencia en la técnica del temple a lo largo de la Edad Media se nos presenta como una práctica usual, tanto en España (Presa, M., et alii, "Oil painting in the late middle ages in Spain», IIC Painting techniques. History, Materials and Studio Practice, Dublín, 1998, 77-81), como en toda Europa occidental (Demailly, S., et alii, «The tecnique of mural paintings in the choir of Angers Cathedral», IIC Painting Techniques. History, Materials and Studio Practice, Dublín 1998, 10-15).
}

Al-Qanțara XXIV, 1 (2003) 109-137 
los últimos estudios que sobre decoraciones parietales se vienen haciendo ${ }^{4}$.

Sin embargo, la pintura mural denominada mudéjar o «de lo morisco» o «de echar cintas», como la nombran los textos coetáneos medievales, que se manifiesta en altos zócalos existentes en la Castilla de los ss. XIII y XIV y en Andalucía del s. XV, presenta como técnica de ejecución el fresco ${ }^{5}$.

Es decir, en España, durante la Edad Media, se da una dualidad técnica en el terreno de la pintura mural, dualidad que se corresponde también con unas características estilísticas contrapuestas:

- La pintura mural gótica, de influjo europeo y carácter figurativo, narrativo y colorista, va a constituir el «arte oficial», y, por lo tanto, va a ornamentar las grandes empresas edilicias del poder: las catedrales, y, a su imagen, las iglesias de cierta relevancia. Es la que se realiza al seco, con temple más o menos graso.

- La pintura «de lo morisco» se caracteriza por servir de ornamentación a edificios, preferentemente laicos, donde la solución de la pintura mural resultaba de mayor economía frente a alicatados o tapices o donde dominaba el gusto determinado de su mecenas. Su paleta es monocroma, lo que, unido a su diseño preferentemente geométrico y repetitivo, la convierte en un método rápido de decoración ${ }^{6}$.

Si como hemos citado técnica y estilística se corresponden, centrando nuestra atención en las fuentes de esa estilística medieval hispánica, estudiadas por acreditados maestros (Kuhnel, Marçais, Torres Balbás, Grabar, Pavón Maldonado, etc), se puede intuir el camino de influencias seguido por la técnica de su realización: así, teniendo en

\footnotetext{
${ }^{4}$ Yarza Luaces, J., Restauración de las pinturas murales del claustro de la catedral de León, Valladolid, 1997; Rallo Gruss, C., «Estudio de las pinturas de San Andrés de Cuéllar», en Informe de la Restauración de San Andrés de Cuéllar, 1996 (sin publicar).

5 Para mayor detalle ver Rallo Gruss, C., Aportaciones a la pintura mural en Castilla de final de la Edad Media. Tradición e influencia islámica, Madrid, 2001. El presente artículo corresponde, en gran parte, a la investigación desarrollada en ese estudio, en el que la autora, bajo la supervisión del doctor en Química Enrique Parra, Universidad Alfonso $\mathrm{X}$, realizó más de cien muestras analíticas de morteros, procedentes de diferentes lugares de España y pertenecientes a pinturas romanas, musulmanas y mudéjares.

${ }^{6}$ Grabar, O., La formación del arte islámico, Madrid, 1981: «... el estuco, por lo tanto, era una técnica de decoración de superficies que podía transformar un edificio de un modo barato y adaptable». Aquí la palabra «estuco», como en otras citas del texto, denomina al mortero de cal y polvo de mármol, calcita o caolín (carbonato cálcico). No hay que confundir esta acepción de «estuco» con la más difundida que equivaldría a relieves realizados con mortero.
} 
cuenta que el diseño geométrico recurrente en la pintura citada «de lo morisco» tiene su más fiel paralelismo en la decoración de entrelazos islámica ${ }^{7}$, la justificación de la perduración de una técnica de ejecución mural (el fresco) puede provenir, igualmente, de una influencia islámica.

Y yendo más allá, si consideramos que los musulmanes fueron en muchos aspectos de la cultura los herederos del mundo greco-romano, nos podríamos plantear las siguientes cuestiones: ¿No perpetuarían aquellos también las técnicas de éstos? ¿No se continuaría, de una forma tradicional en territorio hispano, trabajando la pintura mural al fresco? Anteriormente al Islam, en España existía pintura mural en tiempos romanos ${ }^{8}$, de la que tenemos grandes ejemplos en Mérida, Itálica o Carmona. ¿Fue la pintura mural hispano-musulmana fruto de la tradición que encontraron en el territorio conquistado o trajeron nuevas innovaciones de otros lugares? ¿Siguieron técnicas de pintura mural impuestas por los romanos en Hispania o era la manera tradicional de trabajar la decoración parietal en el país?

\section{Antecedentes de la pintura mural hispano-romana}

El decorar con pintura morteros aplicados en los paramentos para la buena conservación de la estructura arquitectónica, no es algo extraño en la Península y que trajeran los invasores de otras tierras, sino que refleja una continuidad de las tradiciones locales que sobrevivieron a las vicisitudes de los cambios políticos.

Aunque pocos ejemplos de decoración mural, anteriores a la romanidad, han llegado hasta nosotros, sí existen restos de pintura ibéri-

\footnotetext{
${ }^{7}$ Estas comparaciones ya fueron estudiadas en Torres Balbás, L., «Los zócalos pintados de la arquitectura hispanomusulmana», Al-Andalus VII (1942), 395-416; Ocaña Jiménez., M., «Zócalos hispanomusulmanes del s. XII», Al Andalus X (1945), 164-169.

${ }^{8}$ Desgraciadamente no ha llegado hasta nosotros ningún resto de decoración pictórica visigoda. Eso no quiere decir que no existiera, porque sí perduró, como más adelante se citará, en el bajo imperio romano. De la época visigoda contamos con los textos de San Isidoro, donde desaconseja el arte de la pintura por engañosa, lo que viene a confirmar su existencia. Isidoro de Sevilla, Etimologías, ed. de Oroz, J. M. ${ }^{\text {a }}$, Madrid, 1982-3, Libro XIX, cap. X, punto 16, p.451: «Respecto a la pintura. Pintura es la imagen que representa la apariencia de alguna cosa y que, al contemplarla, nos evoca su recuerdo... se trata de una imagen ficticia, no auténtica... al que no hay que dar crédito, pues no es verdad. Por eso hay algunas pinturas que en su afán de representar la realidad auténtica abusan del color y, sobrepasando la realidad misma, conducen a la mentira».
} 
ca parietal descubierta en tumbas, destacando la aparecida en Galera (la antigua Tútugi, en Granada, cerca de Baza) que, desgraciadamente, desapareció a manos de «buscadores de tesoros», quedando como testimonio una cista de piedra con escenas pintadas ${ }^{9}$; otras noticias nos hablan de otros hallazgos en tumbas en varios lugares, como en Jaén ${ }^{10}$. Este tipo de ornamentación también se ha encontrado en viviendas de poblados iberos, así en Cortes de Navarra ${ }^{11}$, siempre localizada en la zona correspondiente a zócalos de paramentos. La técnica descrita en los textos de las excavaciones arqueológicas citadas pudiera corresponder a la del fresco: sobre muros de adobe muy degradado o tapial, se extendió una fina capa de cal, donde se situaron dibujos geométricos realizados a la almagra (óxido de hierro). En ese muro de barro, donde las pinturas aparecieron en la parte baja de las paredes a modo de zócalo, se encontraron restos de paja ${ }^{12}$.

Recordemos esas constantes, características de la pintura mural ibera: localización en zona de zócalos, utilización de materiales como el adobe, el tapial, la cal, la paja, el almagre; motivos geométricos, muy sencillos, repetidos rítmicamente, formando un espacio cerrado por celosía figurada.

\section{De Roma a al-Andalus}

Afortunadamente, para el conocimiento de la pintura mural romana contamos con numerosos ejemplos, tanto en Italia como en la Península Ibérica, e incluso con textos documentales de tratadistas de la propia época clásica. Entre ellos, destaca la obra de Plinio y Vitrubio. Este último dice de la pintura mural ${ }^{13}$ :

${ }^{9}$ García Bellido, A., «La pintura mayor entre los iberos», Historia de España de Menéndez Pidal I, 3, Madrid, 1954, 595-608.

10 Fernández Chicarro, C., "Noticiario Arqueológico de Andalucía», AEA (1955), 322-341. Las fotografias de ese artículo (figs. 9 y 13), nos muestran, sobre un enlucido de cal una simulación pintada de un vallado de cerca semicircular entrecruzado rematado con palmetas. La intencionalidad de la sensación de enrejado, celosía, entramado, ... ¿no nos recuerda a los zócalos almorávides o cristianos de influencia islámica resueltos aquí de manera más tosca?

11 Taracena Aguirre, B., Gil Farrés, O., «Poblados de las Cortes de Navarra», Príncipe de Viana XII (1951), 211-234; Gil Farrés, O., «Extracción de pinturas murales célticas», Archivo de Prehistoria Levantino III (1952), 95-99 y Lám. I.

12 Gil Farrés, O., «Poblados de las Cortes de Navarra», 97.

13 Vitrubio, M., Los Diez Libros de la Arquitectura, traducidos del latín y comentados por Ortiz y Sánz , J. (Imprenta Real 1787), Barcelona, 1987, Libro VII, Cap. III, 174. 
«13. Terminadas las cornisas, se dará la trusilación a las paredes... Al secarse la trusilación se extenderá sobre ella el arenado... Al secarse se repetirá segunda y tercera capa... Después de las tres capas de arenado encima de la trusilación, se extenderá una mano de mortero de cal y grano de sílice... Al secarse esta mano, se dará otra de estuco ${ }^{14}$ compuesto de grano más fino: y después de bien manejada y pulida, se extenderá la tercera de estuco todavía más fino...»

«14. Empleados los colores sobre el estuco todavía fresco, no se van, antes bien permanecen siempre, por razón de que la cal, perdiendo en el horno la humedad de la piedra, y quedando porosa y ligera, por la gran sed que tiene arrebata así las cosas que la tocan, y uniéndose sus diferentes principios en un cuerpo sólido de cualquier figura que sea, después de seca vuelve a su primer estado, pareciendo recobrar las calidades de la piedra».

«15. Por esto los enlucidos bien executados ni la vejez los vuelve escabrosos, ni aunque se estreguen al limpiarlos dexan sus colores, a no ser que se hubiesen dado sin inteligencia y en seco; pero si hicieren con las reglas sobredichas tendrán firmeza, lustre y larga permanencia... A la manera de un espejo de plata, si su lámina es muy delgada, no puede recibir vivo y exacto pulimento ("coloribus cum politionibus inductis»); y el que constare de una plancha más sólida, admitiendo firme bruñido...».

Vitrubio recomienda para la pintura mural preparar el muro con hasta siete capas de mortero: la primera, la trusilación para enrasar las paredes, tres interiores, arenatos, de composición de cal y arena y tres exteriores, de estuco (intonaco). Pero esta fórmula de preparar el muro para una óptima conservación de los enlucidos, que puede suponer un grosor medio de ocho a diez cms, rara vez se cumplía. Cuando estamos hablando de pintura mural romana nos estamos refiriendo a un amplio período de tiempo (seis siglos) y de localización geográfica (todo el Mare Nostrum). Las artes provinciales dificilmente alcanzaban el perfeccionismo que en la metrópoli, ni utilizaban ese número de capas de mortero ${ }^{15}$, ni alcanzaban ese espesor: en el texto de Abad Casal, catálogo de las pinturas hispano-romanas existentes, se da como media de dos a cinco $\mathrm{cms}^{16}$.

${ }^{14}$ La palabra «estuco» tiene el mismo significado de mortero de cal y polvo de mármol, calcita o caolín (carbonato cálcico) que en la nota 6 .

${ }_{15}$ Guiral Pelegrin C., San Nicolás Pedraz, M. ${ }^{\mathrm{a}}$ P., Pintura y mosaicos romanos en Espa$\tilde{n} a$, Madrid 1998, 18: «... Los planteamientos de Vitrubio denotan ser más teóricos que prácticos, y no debemos olvidar el carácter artesanal de estos talleres... Por ello encontramos, en numerosas ocasiones, un número de capas que no coinciden con las aconsejadas por los autores clásicos, y que en pintura provincial se reducen generalmente a tres...».

16 Abad Casal, L., Pintura romana en España, Sevilla, 1982, 272: «... lo normal es que se aplicaran dos o tres capas... La primera, inmediatamente por debajo de la pintura, suele oscilar entre 0,3 y $1 \mathrm{~cm}$ de espesor, siendo frecuente un promedio entre 0,4 y 0,6 cms; la segunda, entre 1 y 2 cms...», 273: «Es imposible, hoy por hoy, sacar consecuen- 
En ningún documento de la época se determina claramente que la pintura mural romana fuera realizada al fresco. Algunos autores se cuestionan si fue realizada a la encaústica ${ }^{17}$, debido al brillo que presenta en superficie. Sin embargo, por pruebas técnicas de reproducción de pintura mural en busca de los mismos efectos finales, $\mathrm{y}$ estudiando detenidamente el texto anteriormente citado, otros especialistas han llegado a la conclusión definitiva ${ }^{18}$ que de fresco se trataba. Su razonamiento, en resumen, se basa en lo siguiente: todos los morteros son de cal y arena, los pigmentos utilizados son compuestos de arcilla que pueden ser pulidos en un determinado momento del fraguado del enlucido, ese brillo que antes mencionábamos se conseguía precisamente mediante ese pulido (... pulimento... firme bruñido...) sin necesidad de adición de cera. Estamos hablando del stucco lustro.

Ese pulimento y ese acabado «como espejo», que también aparece en la pintura hispano-romana, es una novedad respecto a la pintura ibera. Pero no lo son otros aspectos:

- Los adobes y tapiales de arcilla no son desconocidos en las construcciones hispano-romanas ${ }^{19}$.

- Entre los materiales que agregaban a esta mezcla también se podían encontrar elementos vegetales como la paja que impiden que el aglutinante, la cal, se agriete en su secado y consecuente retracción ${ }^{20}$.

cias claras de los revestimientos, de su espesor y número de capas... Lo normal era que los revestimientos tuviesen un espesor de 2 a $5 \mathrm{cms}$, según se puede observar en las decoraciones aún in situ...». Ver cuadros técnicos con medidas, 279 y ss.

17 Defensores de la teoría de la encaústica son Augusti, S., La Tecnica dell'Antica Pittura Parietale Pompeiana, Nápoles, 1950, 313-354 y Cuni, J. y J., «La encaústica pompeyana», Revista de Arqueología n. ${ }^{\circ} 66,67$ y 68 (1986) y «Consideraciones en torno a la encaústica romana», $A E A$ n. ${ }^{\circ} 66$ (1993).

${ }_{18}$ Mora, P., et alii, Conservation of wall paintings, Londres, 1983, 89-97.

19 Abad Casal, L., Pintura romana, 272, nos ilustra con varios ejemplos: «...en aldeas y villas se solía emplear el adobe y el tapial...» en Badalona, en la villa del Romeral en Abesa, en Segóbriga, en Julióbriga, en la villa de Rioseco, en el templo de Azaila (Teruel), en Bílbilis... En el caso de la villa de Astorga, el tapial, compuesto con elementos cerámicos y huesos de animales, se cubre con magníficas pinturas murales.

20 Abad Casal, L., ibidem, 273. Abad Casal, L., «Pinturas romanas en Sevilla», Arte Hispalense 21, Sevilla, 1979, 19: «El muro que se iba a pintar se cubría primero de un número variable de capas de revestimientos... su composición es a base de cal y arena, aunque se les puede agregar otros ingredientes: pequeños guijarros, trozos de ladri1lo, fragmentos cerámicos molidos o machacados, materiales orgánicos, etc...». Además, en la 80 , hablando de los morteros de Itálica de los fragmentos pertenecientes a la 
Grandes conocedores de la técnica constructiva, en terrenos en que se pudiera infiltrar humedad en los muros, agregan a los morteros elementos cerámicos, molidos o en forma de placas más o menos grandes. En distintos lugares se han detectado estas placas cerámicas como capa aislante entre el muro (o ladera rocosa, en caso de estar anexionada la construcción a ella) y los morteros interiores, tanto en Zaragoza como en Mérida ${ }^{21}$.

Tampoco la realización de esas pinturas murales romanas era tan «perfecta» como se ha idealizado: rara vez estaba ejecutada simplemente al fresco sino más bien en una técnica mixta. La técnica del fresco exige una gran rapidez y virtuosismo de ejecución, si no es posible rematarla en poco espacio de tiempo o precisa de correcciones, se termina al seco ${ }^{22}$. En relación con esa rapidez de ejecución que necesita la técnica al fresco en las pinturas hispano-romanas se vinculan una serie de «marcas» que han facilitado el trabajo del artista y que han quedado grabadas en el mortero fresco y posteriormente endurecidas en su fraguado: así las incisiones trazadas mediante grabado del dibujo utilizado para la composición general del diseño.

Coincidiendo con las indicaciones de Vitrubio, y para facilitar la tersura de la superficie y la realización de la pintura, frecuentemente la última capa estaba compuesta con cal y carbonato cálcico o polvo de mármol ${ }^{23}$.

colección de la Casa de Lebrija, concretamente, añade: «... En vạrios existen huellas de elementos... paja, por regla general...», Estos documentos analíticos (Abad Casal cuenta con el apoyo del CSIC de Sevilla para sus estudios), contradicen lo expuesto en García Bueno, A., Medina Flórez, V., «Algunos datos sobre el origen de la técnica de la pintura mural hispanomusulmana», Al-Qantara XXIII, 1 (2002), 213-222, 216: «...los enlucidos de Europa occidental no presentan paja ni pelo animal en su composición, mientras que en Oriente Medio encontramos con frecuencia estos componentes...».

${ }^{21}$ Guiral Pelegrin C., Martín-Bueno, M., Bilbilis. Decoración pictórica y estucos ornamentales, Institución Fernando el Católico, Zaragoza, 1996, 216: «... Placas de cerámica ("podium" del templo) que presentan incisiones para facilitar la fijación del mortero. $\mathrm{Su}$ finalidad es evitar que la humedad procedente de la roca, deteriore la superficie pictórica..». Guiral Pelegrin C., San Nicolás Pedraz, M. ${ }^{a}$ P., op. cit. 22: «... Hay que mencionar la disposición de "tegulae mammatae" para combatir la humedad (Tiermes, Soria)...», Abad Casal, L., Pintura romana en España, 273, acerca de una estancia termal junto a la Casa del Mitreo.

22 Abad Casal, L., «Pinturas romanas en Sevilla», 81.

23 Acerca de morteros de cal con áridos calizos (no silíceos) nos dicen G. ${ }^{a}$ Ramos, G., Justo, A., y Abad Casal, L., «Estudio fisico-químico y mineralógico de una serie de pinturas y revestimientos de Itálica (Sevilla), AEArq, 133-134 (1976), 141-157: «... para el so- 
Iconográficamente hablando, la disposición de la ornamentación parietal romana era muy rica, cubriendo el total del paramento. El diseño más frecuente era la división horizontal de la pared en tres zonas, siendo la más importante la central, donde se representaban las escenas más elaboradas. La parte más baja, siempre considerada zócalo, era más sencilla, por ser la zona que iría cubierta por el mobiliario, por ser la que más pudiera sufrir la agresión humana y la más fácil de reponer; muchas veces se limitaba a imitación de mármoles ${ }^{24}$.

Dentro de los motivos decorativos, existen los que Abad Casal denomina «en relación continua», y es frecuente que los diseños repetidos, que predominarán a partir del s. III, sean de carácter geométrico. Así nos ocurre en Carmona, en Itálica (ambos en Sevilla), en la villa

porte inmediato a la pintura se añadió una gran cantidad de calcita molida» (p. 157), con un total de veintiocho muestras de diferentes ambientes estudiadas. De los mismos autores, «Estudio físico-químico y mineralógico de algunas muestras de pinturas y revestimientos murales de Bolonia (Cádiz), AEArq. 138 (1977-78), 295-309: «1. De los resultados del análisis químico de los morteros y soportes de Bolonia se desprende que el contenido en carbonatos se éstos es, en general, más alto que el de aquellos. Ello se debe a que el material empleado como soporte de la pintura era de mejor calidad y más fino que el del mortero, con un tanto por ciento más elevado de polvo de mármol o calcita...» (p. 302), con un total de diez muestras, de distintas habitaciones. También aparece esa capa de estuco en otros lugares: Santa Eulalia de Bóveda (Abad Casal, L., Pintura romana en España, 149: «... según noticias de López Martí (1934, 21-22) las paredes de Santa Eulalia presentan dos capas de revestimiento, una gruesa, de $7,5 \mathrm{cms}$, en contacto con el muro; y otra superior de $3 \mathrm{cms}$. Por encima de ésta se aplicó una delgada capa de estuco...»), Astorga (Ibidem, «... por último, se aplicó una tercera capa de apenas $1 \mathrm{~cm}$ de espesor de piedra de mármol pulverizada que recibió la decoración pintada»), Mérida en la Casa del Teatro, Termas de Campo-Valdés (Alvargonzález, C., Termas romanas de Campo Valdés, Gijón, 1965, 26); Bilbilis (Lapuente Mercadal, P., «Análisis de morteros», Bilbilis. Decoración pictórica y estucos ornamentales, Zaragoza, 1996, 504-505), etc. Resultados semejantes son los obtenidos en las muestras procedentes de la Casa Romana de la P. ${ }^{a}$ de la Reina Juana (Segovia), fragmento depositado en el Museo de la ciudad, analizadas por la autora; o en los encontrados en San Pedro Mártir (Toledo), analizados en el IPHE.

En cambio, en García Bueno, A., Medina Flórez, V., "Algunos datos...», 213-222, 221 se dice, a modo de conclusiones: «... los (morteros) hispano-romanos examinados (al parecer, solamente uno, de Guadix)... a pesar de que también son de cal, éstos presentan un árido compuesto solamente por arena de sílice sin adiciones de materia orgánica...». No se pueden extrapolar, aportando una sola muestra de mortero (Guadix), indeterminada en datación, diferenciaciones entre los morteros propiamente itálicos y los hispano-romanos en virtud de que aquellos tienen polvo de mármol en su composición y éstos únicamente arena; existen abundantes analíticas que prueban lo contrario.

${ }^{24}$ Incluso en algunos casos, como en la villa de Casale, Villa Armerina, en Sicilia, en los paramentos exteriores, se limita a una línea o una zona plana roja rellena de almagre, exactamente igual que encontramos en la Alcazaba de Málaga y tantos otros lugares de decoración simple. 
de Marbella (Málaga), en Clunia (Soria), en la Alcudia (Elche, Alicante), y otros muchos más. Hay que destacar, dentro de lo aparecido en la Península, la decoración de un edificio de planta semicircular en Boca de Lagoa, cerca de Troia (Portugal), de finales del s. IV ${ }^{25}$, por su gran similitud con los fragmentos conservados en Granada, procedentes de Madīnat Ilbīra; y, en la provincia de Soria, la torre de Vildé, donde sobre un mortero de cal y arena se extiende una decoración muy sencilla de línea roja formando octógonos que nos recuerda el «tirar cintas» islámico y «de lo morisco» ${ }^{26}$.

Según nos alejamos de la época clásica (ya sea por los períodos de inestabilidad política y social a partir del s. III), las técnicas constructivas se empobrecen: los edificios disminuyen de tamaño, los sillares muchas veces devienen aparejos, los morteros se debilitan... El occidente romano en los ss. V, VI y VII languidece, mientras en su parte oriental presenta gran vitalidad y destaca por su riqueza artística, produciéndose obras como Santa Sofía.

El arte hispano bajo la dominación visigoda, en relación con la construcción y su ornamentación, se empobrece pero no desaparece; desafortunadamente, de esa época no nos ha llegado ningún resto pictórico. Pero esto no quiere decir que no existiera; testimonio de ello es que en el arte astur, contemporáneo del islámico, y que se declaraba «heredero de los godos» (como lo prueba la redacción de la Chronica Visigotorum en tiempos de Alfonso III, para justificar su legitimidad como descendiente de los reyes de Toledo), tenemos ejemplos de ornamentaciones pintadas. Entre ellos destacan las pinturas de Santullano de Prados (Oviedo). Según Arias Páramo, son pinturas realizadas «al fresco» con profusión de dibujo preparatorio grabado, testimonio de un tiempo limitado de ejecución característico de la técnica citada ${ }^{27}$. Estilísticamente presentan una gran vinculación con modelos clásicos y bizantinos.

En cuanto a la pintura del «arte de repoblación» contamos con pocos testimonios. Entre ellos, el de Santiago de Peñalba: oculta su de-

${ }^{25}$ Nunes Pedrodo, R., «La «basilique» de Troia, un décor luso-romain du IV s. ap. J.C.», La peinture funéraire antique, coord. Barbet, A., París, 2001, 305-397.

${ }^{26}$ Este monumento se encuentra en clara «vía de extinción» en la actualidad. Se trata de un monumento funerario turreiforme con restos de policromía amarilla, verde y roja, la más abundante, en sus dos estancias superpuestas. Se data en el s. Il d. C. (Abad Casal, L., Pintura romana en España, 247).

27 Arias Páramo, L., La pintura mural en el reino de Asturias, Oviedo, 1999, 53-63. 
coración ${ }^{28}$ bajo encalados posteriores, está siendo intervenida en la actualidad. Habrá que esperar los resultados de esa actuación y la analítica de las muestras tomadas para poder comprender hasta qué punto manifiesta influencias islámicas y/o la continuidad de una antigüedad languideciente. Sin embargo, de lo que se adivinaba en las calicatas efectuadas previamente, se podía deducir que los motivos decorativos, geométricos o florales, se repetían rítmicamente. Alguno de ellos se vincularía estilísticamente con motivos califales de raigambre clásica, existentes en la Mezquita de Córdoba ${ }^{29}$ y en monumentos hispanos previos tardoantiguos.

\section{Pintura mural hispano-musulmana}

Se reconoce la admiración, emulación, asimilación y continuidad del arte omeya por el mundo antiguo romano ${ }^{30}$; sus primeras manifestaciones artísticas en el Asia Mediterránea son las mezquitas donde reaprovechan las antiguas basílicas paleocristianas con una simple reorientación hacia La Meca. De los fragmentos de sepulcros antiguos que van apareciendo en Madīnat al-Zahrā' y del emplazamiento de capiteles romanos en la Mezquita de Córdoba se puede deducir que los musulmanes hispanos, y entre ellos sus soberanos, hallaban tan grato el arte clásico que reencuentran en la tradición hispana ${ }^{31}$, como sus predecesores asiáticos en la tradición mediterránea. Así lo reconocen sus propios tratadistas: Ibn Jaldūn, sabio de la mitad del s. XIV, que visita las cortes de Muhammad V de Granada y Pedro I, exalta la perfección de las artes en España gracias a la subsistencia de tradiciones bien enraizadas ${ }^{32}$.

28 Menéndez Pidal, J., «Las pinturas prerrománicas de la iglesia de Santiago de Peñalba», $A E A$ XXIX (1956), 291-295.

29 Rallo Gruss, C., Aportaciones a la pintura mural en Castilla, 154.

${ }^{30}$ Maravall, J. A., El concepto de España en la Edad Media, Madrid, 1992, 54.

31 Para un recorrido de recopilación de modelos clásicos en el arte islámico ver Kuhnel, E., «Lo antiguo y lo oriental como fuente del arte hispánico islámico», Al-Mulk 4, 1964-65, 5-21. También, del mismo autor, «Oriente y Occidente en el Arte medieval», AEA XV, 1942, 92-98.

32 Ibn Jaldūn, Prolégomènes, (traducción del Marqués de Slane, París, 1862-68), 2. a parte, $5{ }^{\text {a }}$ sección, $361:$ «... mais ces arts sont loin d'avoir atteint la perfection, ainsi que cela se voit encore de nos jours en Espagne. Nous trouvons dans ce pays les restes de plusieurs arts encore subsistants et bien conservés, ils se reconnaissent dans tout ce que les habitudes établis dans ces villes ont appelé à l'existence. Citons, comme example, la maçonnerie... 
Sánchez Albornoz va más allá, habla de: «... la perduración en España posterior al año 700 de muchos rasgos de la España anterior a Cristo» ${ }^{33}$. El arte hispano-musulmán, sobre todo en sus comienzos en el arte califal, es todo un proceso de fusión de elementos visigodos, romano-ibéricos, romano-sirios, bizantinos ${ }^{34} \mathrm{y}$ árabes, pero con una base muy fuerte de tradición local que se va a manifestar, sobre todo, en su decoración.

Si la implantación de una nueva religión exige un cambio de espacio arquitectónico creado para tal fin, en la pintura mural se pueden seguir utilizando, sin embargo, las viejas técnicas tradicionales ${ }^{35}$ :

- Para los muros se utiliza con frecuencia el barro o limo, ya usado desde tiempos neolíticos, por ser el material de más fácil obtención en aquellos lugares donde no abunda la piedra (como en Oriente Próximo o Egipto). Puede adoptar dos formas: el adobe (țüb), ladrillo sin cocer, es decir, paralelepípedo que se realizaba a partir de un molde; y el tapial (țäbiya $)^{36}$, fabricado a partir de las capas sedimentarias arci-

vous verrez que la practique des arts est bien enracinée chez les espagnols... les arts se sont conservés chez eux, parçe que la civilisation de la vie sédentaire avait eu le temps de s'y affermir pendant la durée de plusieurs dynasties, celle des Goths...».

Sin embargo, Torres Balbás nos pone en relación la costumbre hispano-musulmana de decorar las partes bajas de las habitaciones con zócalos pintados con antecedentes del Oriente asiático y el arte helenístico, V. Torres Balbás, «Los zócalos pintados», 395: «... este sistema de decoración mural cuyos antecedentes se encuentran en el Oriente asiático...». En realidad no cita ningún ejemplo. En la zona del Oriente próximo (Siria, Libia, Jordania, etc) no existen en la actualidad modelos de este tipo de ornamentación.

${ }^{33}$ Sánchez Albornoz, C., El Islam de España y el Occidente, Madrid, 1974, 104.

${ }^{34} \mathrm{El}$ arte de la Edad Media, ya en Oriente, como en Occidente (cristiano e islámico) se basa en el gran legado de la romanidad. Por ello el desenvolvimiento de las distintas culturas puede ofrecer manifestaciones paralelas sin que, necesariamente, sean unas las fuentes de las otras, aunque existan intercambios innegables entre ambas. Es lo que en Biología se denomina "congruencia evolutiva».

${ }_{35}$ Marçais, G., L'Architecture musulmane d'Occident, París, 1954, 181 : «Mais si le culte islamique a imposé de nouvelles ordonnances architecturales, il a laissé le champ libre à la main-d'oeuvre locale pour l'enrichissement superficiel des édifices. C'est dans le décor que nous trouvons les traces de la tradition wisigothique...».

${ }^{36}$ El nombre de tâbiya, utilizado por los hispano-musulmanes, según Torres Balbás, L., Ciudades hispanomusulmanas, Madrid, 1971, 557 está testimoniado en el Magrib al-aqșà

Bazzana, A, Maisons d'Al-Andalus, Madrid, 1992, nos cita textos donde se alude a este nombre, en una epigrafia de Murcia del s. XIII, en la construcción de las murallas del s. XI de Almería, en las de Huesca de finales de ese siglo, y en las de Sevilla, ...en el s. XIV en las murallas de Fez, y posteriormente en las de Tetuán.

Ibn Jaldūn nos cuenta la manera de utilizar este procedimiento para hacer los muros de las viviendas. Su descripción es la más elocuente que podemos encontrar: «... otro 
llosas ${ }^{37}$, masa que forma directamente el muro vertical con la ayuda de dos «tapias» o superficies planas, generalmente de madera, que se colocan como barreras a los lados de la anchura prevista. Para su ejecución se eligen arcillas de gran poder adhesivo y plasticidad. A ellas se puede agregar, para reforzar su resistencia, una parte de cal y/o paja. La paja es lo que se llama un aditivo, es un material que se añade al mortero con el fin de reforzar la adhesión o ciertas propiedades. Tradicionalmente se añadía paja, pelos de animal o leche ${ }^{38}$. Su función es doble: evita agrietamientos durante el fraguado del mortero y trabaja como amortiguador de cambios bruscos de temperatura.

Ambos materiales, adobe y tapial, tuvieron gran éxito en las edificaciones defensivas medievales islámicas ${ }^{39}$.

modo de construir (respecto a la construcción con piedra) es construir las paredes con arcilla simplemente. Sirven para ello dos planchas de madera solamente, cuyo largo y ancho varían según los usos locales; pero sus dimensiones son, en general, cuatros codos por dos. Se levantan estas tablas sobre los cimientos (ya preparados), teniendo en cuenta mantener entre ellas el ancho que el alarife haya juzgado necesario darle a los cimientos. Entre ellas se sostienen en el medio travesaños de madera que allí se ajustan con cuerdas o lianas. Se cierra con otras dos planchas de pequeña dimensión el espacio vacío que queda entre ellas, y allí se vuelca una mezcla de tierra y cal que se apisona inmediatamente con dos mazos construidos expresamente para este objeto. Cuando la masa está bien comprimida, y si la tierra ha sido perfectamente combinada con la cal, se añade más mezcla hasta colmar el espacio. Las partículas de tierra y de cal se encuentran entonces bien mezcladas para formar un solo cuerpo. Entonces se retiran las planchas de la parte del muro ya formado y se continúa hasta que las masas de tierra, ordenadas en líneas superpuestas forman una pared como si formaran parte de una sola pieza. Esta clase de construcción se llama taba (tablilla), el obrero que la hace recibe el nombre de tawwäb»: Prolégomènes, traducción de Slane, 372.

37 En Valencia se han encontrado fosas de extracción de material arcilla en el propio interior de las viviendas. V. Pascual, J., et alii, «La vivienda islámica en la ciudad de Valencia, una aproximación de conjunto», La casa hispano-musulmana, Granada, 1990, 308.

38 Ver técnicas de las culturas de Asia y precolombinas, así como las bizantinas, en Mora, P., et alii, Conservation of Wall Paintings, 75-85, 107-115. El uso de aditivos en los morteros, aunque muy común en la tradición oral (la sangre, el semen, la leche, muchas veces relacionados con la pintura mural desde tiempos prehistóricos), no ha sido suficientemente comprobado y existen pocos estudios sobre ello. Uno de ellos, donde se afirma haber encontrado en morteros medievales trazas de cerveza, cera de abejas, clara de huevo, gluten, goma arábiga, malta, arroz, cola, azúcar y/u orina, es el artículo de Sickels, L. B., "Organics vs. Synthetics: their use as additive in mortars», Mortars, Cements and Grouts, ICROM, Roma, 1981, 25-51.

39 Baños de la Encina, o el actual Vacar, topónimo que deriva erróneamente del árabe 'aqabat al-baqar, o "cuesta de los bueyes», ambos del s. X, conservan de forma fácilmente reconocible las cajas de los tapiales con que están construidos sus muros. 
Este tipo de construcción se identifica tanto con el modo de construir islámico que algunos especialistas ${ }^{40}$, nos dicen que «obra moresca» equivale a decir tapial ${ }^{41}$.

- Sobre el muro, ya sea de tapial, adobe, ladrillo o piedra, varias capas de mortero de cal y arena lo protegen. La cal se menciona ya en la Biblia ${ }^{42}$, conociéndose desde tiempos remotos sus propiedades de uso en enlucidos de muros, por su carácter adhesivo y protector frente a la humedad; de cal se enlucieron los primeros poblados neolíticos del Asia Mediterránea ${ }^{43}$. Se obtiene a partir del carbonato cálcico $(\mathrm{Ca}$ $\mathrm{CO}_{3}$ ) que se presenta en la naturaleza en rocas carbonatadas como calizas y mármoles. Calcinando este material a grandes temperaturas, se obtiene óxido cálcico, llamado también «cal viva», que mezclada con agua da lugar a una pasta, más o menos espesa, que es la que se utiliza para revocar los muros. En contacto con el aire, se produce un proceso de fraguado, resultando una superficie resistente y duradera.

40 Torro, J., Ivars, J., «La vivienda rural mudéjar y morisca en el sur del país valenciano», La casa hispano-musulmana, Granada, 1990, 73-81, 75.

${ }^{41}$ En la actualidad, en los pueblos del Sáhara se sigue construyendo con adobe y tapial mezclado con paja cortada. También se utilizaba este método en regiones áridas como Arabia y ciertas zonas de Mesopotamia. El ladrillo cocido fue utilizado en la construcción de Samarra, capital de los Abbasíes, y en Túnez, en la misma época.

42 Deuteronomio 5-27, 2 apud Alvarez Galindo, C., et alii, «Historia de los morteros», Boletín Informativo del JAPH (1995), 52-59.

${ }_{43}$ Aunque Vitrubio y Plinio, entre otros, nos hablan de la cal, ateniéndonos al panorama hispano y a tiempos medievales, es definida por San Isidoro (Isidoro de Sevilla, Etimologias, ed. de Oroz Reta, J. M. ${ }^{\text {a }}$, Libro XIX, cap. X, punto 19, p. 447) como «la cal viva es así llamada porque, siendo fría al tacto, en su interior contiene oculto el fuego. Y así, rociándola con agua, al punto el fuego escondido se pone de manifiesto. Su naturaleza produce un efecto admirable: una vez que ha ardido, se enciende con agua, que es lo que suele apagar el fuego; y, en cambio, se apaga con el aceite, con lo que suele encenderse el fuego. Su empleo es imprescindible en la construcción de edificios, pues una piedra no puede soldarse fuertemente con otra si no es fijándolas con cal».

Alfonso X (Alfonso X, Lapidario, ed. de Brey, Castalia, Valencia, 1968, 18) la caracteriza como «de su naturaleza es caliente y seca, hánla en la mayoría de los lugares de la tierra, $y$ en todas las fuertes labores que los hombres han de hacer se ayudan mucho de ella, porque junta muy fuerte las piedras unas con otras y cierra los lugares horadados, de manera que no puede salir por allí el agua; por ello adoban los hombres con ella caños, y cierran las naves y pónenla en otra cosa donde quieren que el agua no entre».

También es nombrada en las Cortes de Valladolid de Pedro I (Cortes de los Antiguos Reinos de León y Castilla, ed. de Colmeiro, M., Madrid, 1883, 80-81, 95 y 179), distinguiendo los precios entre «la cal regada» y «la cal por regar» (por el «caffiz», tres maravedíes, por la fanega, siete dineros, respectivamente), para Toledo, y cinco maravedíes para Sevilla. Para Enrique II, en las Cortes de Toro de 1369, el precio de la fanega sería diez dineros. 
La preparación del muro con esos morteros de cal también es comentada por Ibn Jaldūn ${ }^{44}$, que, curiosamente, destaca la operación de «frotar» los morteros de cal en su proceso de fraguado (¿simple recuerdo al «bruñido» mencionado por Vitrubio?). La analítica de distintas muestras islámicas ha coincidido en dar como resultados morteros de cal y arena, sin aglutinantes orgánicos. Frecuentemente, se encuentra paja machacada utilizada como aditivo.

Se hace imprescindible comentar que, igual que ocurría en las técnicas parietales del mundo antiguo romano, los morteros varían a lo largo de los siglos de dominio islámico, tanto en su calidad como en su grosor (ambas características están imbricadas intrínsecamente): no se puede comparar el espesor de capas y su número en los morteros de Madīnat al-Zahrā', con las cada vez más finas del período nazarí.

- Para la pintura, aplicada mientras el mortero está fresco, se utiliza frecuentemente el rojo. El almagre, $u$ ocre rojo, es un pigmento, óxido de hierro, que contiene diversas impurezas que le van a caracterizar con una tonalidad que va desde un naranja hasta un marrón pasando por rojo. Es muy común en la naturaleza y de fácil preparación: basta un simple molido. Es el mismo color que los italianos denominarán sinopia, y en la pintura actual se califica de tierra o rojo de Sevilla (por la gran abundancia que existe en tierras andaluzas).

La época califal no recuerda únicamente tiempos de la romanidad en su iconografía, sino en su modo de hacer. La pintura mural califal nos ha dejado restos en tres grandes monumentos: Madīnat al-Zahrā', que estudiaremos a continuación como ejemplo del conjunto, los Alcázares de Córdoba, con restos pictóricos en el Museo Arqueológico de esta ciudad y en los baños y Madīnat Ilbīra, cuyos fragmentos se conservan en el Museo de Granada ${ }^{45}$.

${ }^{44}$ Ibn Jaldūn, Prolégomènes, 372: «... Otra rama del arte de construir consiste en revestir los muros con cal, que se deslía en el agua y que se deja a continuación fermentar durante una o dos semanas. Adquiere entonces una temperatura conveniente, habiéndose desembarazado de la cualidad ígnea que tenía en exceso y que le habría impedido fraguar. Cuando el obrero juzga que está bien preparada, la aplica al muro y la frota hasta que queda adherida».

${ }^{45}$ Los fragmentos de Madinat Ilbïra tienen la peculiaridad de estar realizados con la técnica del esgrafiado (superposición de dos morteros de diferente color, donde se arañan ciertas zonas del superior para lograr un dibujo). La técnica tampoco es nueva, precisa- 
Madīnat al-Zahrā', destruida a principios del siglo XI, fue el gran sueño esplendoroso y efímero al mismo tiempo, cuyos hallazgos sirven como hito de datación del arte musulmán. El lugar de su ubicación fue olvidado durante mucho tiempo; llamado "Córdoba la Vieja», era donde localizaba Ambrosio de Morales la ciudad romana ${ }^{46}$. Las excavaciones empezaron en 1910 con Velázquez Bosco ${ }^{47}$ (con un preludio de Pedro de Madrazo en 1854) y aún hoy en día no han terminado.

De su ornamentación en relieve contamos con numerosos restos, ya que la técnica constructiva se organizaba por medio de placas de arenisca o mármol labradas y colocadas sobre sillares de piedra de peor calidad. Esos sillares fueron reaprovechados en otras construcciones, y el mármol muchas veces pulverizado y llevado al horno para la obtención de cal, pero se ha conservado gran parte de los relieves realizados en arenisca ${ }^{48}$.

La pintura mural que guarnecía, bien directamente o sobre placas de arcilla cocida que recubrían las paredes ${ }^{49}$, la piedra de construcción, no ha corrido la misma suerte, por lo que en la actualidad está en

mente en las viviendas romanas de la cripta del Museo de Mérida existen ejemplos de ornamentaciones con esta técnica.

46 Ambrosio de Morales, Antigüedades de España, MDXXV, 114, Córdoba la Vieja: «... Y pruebase el aver edificado de nuevo Marcelo toda la ciudad, y en el sitio de Cordoba la Vieja y por muchas razones. Lo primero, todo el sitio es perfectamente cuadrado, assi que se vee, como lo esquadraron por cordel con mucho cuydado....».

47 Velázquez Bosco asimismo es el autor de las excavaciones de la villa musulmana en que él creyó reconocer la Alamiriya. Allí encontró también «... las paredes... guarnecidas de estuco con un zócalo de 0,50 metros de altura, de color rojo con franjas horizontales blancas, y en algunos puntos con decoración pintada e inscripciones... De la misma clase de estuco y de color rojo estaba guarnecido el estanque, lo que todavía alcanzó a ver Pedro Díaz de Rivas en los de Medina Azzhara, estuco que tenía en aquel por objeto, además de decorarlo, el de evitar las filtraciones por las juntas de la cantería y por las grietas de la roca natural, en parte utilizada...» (Velázquez Bosco, R., Medina Azzahra y la Alimiriya, Madrid, 1912, 30-31).

48 Precisamente este monumento presenta un curioso problema para su restauración, tiene la piel pero le falta el esqueleto. Como soluciones, ahí está la anastilosis efectuada en el Salón Rico.

49 Esta estratigrafía de piedra, placa de barro cocido y morteros de cal y arena, el último de los cuales se ornamentaba con un zócalo en almagra, la podemos ver reproducida en la actualidad en la casa del baño, adyacente al Salón Rico. No es una técnica novedosa, como ya hemos mencionado es heredada del mundo romano: recordemos las placas de cerámica (tegulae mammatae), que presentan incisiones para su fijación al mortero bajo pintura mural de Bilbilis o de Termancia. Aquí también se utiliza como aislante en zonas donde la humedad proveniente de la roca podría llegar a agredir la decoración. 
gran parte perdida. Esta mala conservación se debe, no ya a los morteros, ricos en cal (a veces hidráulica) con espesores de hasta $10 \mathrm{cms}$, sino al deterioro de la arenisca del propio muro constitutivo de la edificación y al urbanismo dispuesto en terrazas con un mal funcionamiento reológico. Ese problema de mala conservación fue detectado, en multitud de ocasiones, mientras la ciudad palatina fue habitada: se observan clavos de sujeción de enlucidos bufados, y en algunas partes existen hasta tres estratos de decoración iguales, repuesto uno sobre otro cuando el inferior estaba en mal estado, como un tratamiento normal de mantenimiento.

Sobre esos morteros se extendía la pintura en color rojo, realizada con almagre, que sólo invadirá la zona de los zócalos ${ }^{50}$. Antes de realizarla, el diseño se ejecuta, con ayuda de compás, cartabones y regla cuando el mortero está fresco, dando un resultado de un dibujo grabado. En la pintura no existe aglutinante como vehículo, por lo que es, presumiblemente, una pintura al fresco.

El color era un elemento esencial en el arte decorativo califal. Si ese color no se conseguía por los propios materiales constructivos (mármoles de distintos colores como el morado, revestimientos de mosaico, taracea de ladrillo, suelos teñidos en masa), se decoraban los elementos con policromía: la sillería de las torres cubríase con un enlucido de cal y arena en donde se imitaban sillares con despiece de soga y tizón a color. Muchos de los paramentos del camino de ronda bajo aún presentan esta ornamentación en sus muros: un doble llagueado en rojo sobre blanco simula esos sillares a soga y tizón.

En los baños, sus bóvedas se cubrían totalmente con rojo almagra ${ }^{51}$, en los cimacios del Salón Rico aún se podían descubrir trazas de decoración geométrica a la almagra; en los de la mezquita, los restos eran rojos y azules. Para Torres Balbás, las partes lisas irían igualmente decoradas con pintura de motivos arquitectónicos fingidos;

${ }^{50}$ Comparando la localización de la zona de mayor importancia ornamental en el arte hispano-musulmán con otra decoración mural correspondiente al período romano, se percibe que ha cambiado el concepto ornamental de la vivienda: ahora, la franja decorada se sitúa junto al suelo, en un espacio más bajo que en el período clásico donde ocupaba la parte central de la pared. ¿Se relaciona este cambio con los usos y costumbres de cada cultura? En el Islam, la vida social se desarrolla a ras del suelo, en tiempos romanos se utilizaban sillas y triclinia, la mirada se situaba en un nivel más alto.

51 Vallejo Triano, A., «El baño próximo al Salón de Abd al-Rahmán III», Cuadernos de Madinat al-Zahrā' 2 (1987), 145. 
para Pavón Maldonado, quedarían en color de estuco blanco para «... confirmar, una vez más el equilibrio que siempre puso el musulmán occidental entre las partes decoradas y amplias superficies lisas de color blanco» ${ }^{52}$.

Los zócalos de los paramentos eran de diverso tipo: simplemente de mármol, o rematados por una cenefa pintada, en rojo de $8 \mathrm{cms}$, como nos describe Félix Hernández; o con una zona totalmente roja, de 56 a $60 \mathrm{cms}$ de alto, que finalizaba en una banda blanca y otra roja, cada una de $6 \mathrm{cms}$ de altura (de este tipo aún subsisten varios ejemplos en las habitaciones cercanas al Salón Rico y otras zonas). Es un elemento muy repetido en interiores de salas; a partir de este zócalo, la pared se enlucía con simple mortero blanco, hasta una altura de más de $3 \mathrm{~ms}$ (se puede constatar por huellas de techo a esa altura) ${ }^{53}$.

También existían otras zonas parietales de decoración pintada más elaborada; los temas utilizados coinciden con los que decoran, en labra, los relieves esculpidos o los empleados en los pavimentos ${ }^{54}$.

Entre la ornamentación de Madīnat al-Zahrā', se trate del material de que se trate, podemos distinguir dos temáticas recurrentes, que suelen manifestarse por separado, sin mezclarse (acompañadas en ocasiones por franjas epigráficas). En repetidas ocasiones tienen vinculación con un origen clásico, como nos muestra Kubisch. Por un lado, temas florales de grandes roleos, tanto esculpidos en la piedra, con gran profundidad, utilizando el trépano como fieles herederos de los relieves tardo romanos del Asia Menor (ejemplo de ello lo tenemos en la ciudad de Gerasa), como en los restos de pintura mural que decoran la escalera de la casa del cocinero real, situada en la zona de servicios, contigua al Salón Rico. Este importante cortesano, cuya mansión se ubicaba junto a las cocinas (de las que se conserva el horno de pan), poseía una vivienda de dos pisos, como lo atestigua la escalera en piedra cuya ornamentación mural permanece in situ, se trata de un dibujo floral muy clásico. Otros fragmentos de motivos vegeta-

52 Pavón Maldonado, B., Memoria de la excavación de la Mezquita de Medinat al-Zahra, Madrid, 1966, 122.

53 Esta misma decoración, coincidentemente, es la que presentaba las Termas romanas de Segóbriga (Cuenca), hoy reproducida en la simulación virtual que se ofrece en el complejo arqueológico.

54 Esta misma observación la encontramos en Kubisch, N., «La decoración geométrica del Salón Rico de Madinat al-Zahra», El Salón de Abd al-Rahman III, Córdoba, $1995,70$. 
les fueron arrancados por su pésimo estado de conservación en los años 80 y permanecen hoy día depositados en el IPHE de Madrid.

Por otro, el tema geométrico es recurrente en muy diferentes materiales y espacios:

- En los suelos formados por baldosas de barro cocido con incrustaciones de caliza amarillenta (cuando no eran de mármol simplemente blanco, o con tierra y almagre apisonada en las casas más humildes).

- En los relieves esculpidos en las placas pétreas de las paredes, y cuyos fragmentos se extienden cubriendo los suelos de las grandes terrazas abiertas delante del Salón Rico.

- En los pocos restos de pintura mural que hasta nosotros han llegado y que se pueden observar en las paredes del canalillo que conduce hacia el Salón Rico. Semejantes a estos motivos son los fragmentos de pintura mural, rojo sobre color mortero, que reproducen Torres Balbás y Pavón ${ }^{55}$ en el área del Pórtico; reducidas sus dimensiones por una falta de conservación, fueron restaurados en 1987. También geométricas fueron las pinturas que recoge Velázquez Bosco ${ }^{56}$ en el camino de ronda, a base de cuadrados, hexágonos y rectángulos, y otro resto en el camino de ronda alto, sobre una jamba de una puerta, que se conserva muy alterado ${ }^{57}$.

De todos ellos, un testimonio interesante es el recogido en una fotografía de Félix Hernández en el intradós del arco de ingreso al pasadizo entre las dos terrazas elevadas; se trata de un dibujo lineal, sencillo, sobre el mortero del fondo, pero ya con división de espacios y un entrelazo muy simple ${ }^{58}$. Es decir, el embrión del diseño que después será tan característico de la pintura parietal hispano-musulmana.

Este inicio del uso del lazo y entrelazo en el arte califal, por otra parte herencia del mundo romano ${ }^{59}$ aunque desarrollado con un concepto distinto, lo destaca igualmente Fernández-Puertas. Su artículo,

55 Torres Balbás, L., Historia de España, t.V. España musulmana, Madrid, 1957, 712, Fig, 547, Pavón Maldonado, B., Memoria de la excavación..., 120.

56 Velázquez Bosco, R., Medina Azzahra, Lám. XXIII.

57 Estos motivos decorativos están fotografiados y recogidos en Torres Balbás, L., en Historia de España, 712, 713, 402-403, dibujos 259 (p. 461) y 260 (p. 461); y Pavón Maldonado, B., Memoria de la excavación..., 120.

${ }^{58}$ Reproducido en el texto de Torres Balbás, L., Historia de España, 712.

59 Es abundante en muchos mosaicos romanos y bizantinos. Por citar algo más próximo a Madīnat al-Zahrā', en el propio Museo Arqueológico de Córdoba se encuentra una cancela visigoda, cuyo motivo decorativo está constituido por una estrella de seis puntas 
en donde analiza el arte Omeya oriental, basándose en los ejemplos de los palacios de Jirbat al-Mafŷar y Qașr al-Jayr al-Garbī, propone que en la realización de su ornamentación se limitan a: «1) unas reglas inalterables, 2) un sistema proporcional fijo, 3) unos cánones fijos que le dicta la propia disciplina de la geometría. Si se atiene a estos tres principios, el artista puede ampliar y desarrollar sus ideas constantemente» ${ }^{60}$.

También existían temas figurativos. Aunque éste es un punto que nadie discute dado el hallazgo de variadas figuras de arte mueble encontradas, hay que destacar la pintura mural aparecida en el camino de ronda donde se representaba la cabeza de un guerrero, reproducida por Torres Balbás ${ }^{61}$. Desgraciadamente en la actualidad sólo queda su huella.

Se ha constatado la utilización de la pintura como ornamentación de las moradas islámicas en cualquier tiempo. En cada período islámico, califal, taifa, almorávide, almohade o nazarí, en esa vía de expresión cultural se desarrollaron más los aspectos concordantes con sus ideas filosóficas y planteamiento de vida, pero siempre en una línea continua y de desenvolvimiento razonado.

Por ello, si con los reinos taifas, continuadores y admiradores del período califal, en el arte sigue apareciendo el elemento figurativo (recordemos la arpía de Balaguer, en relieve de yeso con policromía), durante el período almorávide y almohade es recurrente el motivo geométrico del entrelazo ${ }^{62}$.

De esos períodos, aunque se han perdido grandes ejemplos de pintura mural ${ }^{63}$, recientemente se están descubriendo otros en excava-

cuyos lados están formados por cintas entrelazadas, exactamente igual a las islámicas posteriores.

${ }^{60}$ Fernández Puertas, A., «Lazo omeya oriental: I. Serie hexagonal», Homenaje al profesor J. M. ${ }^{a}$ Fórneas Besteiro, Granada, 1995, 1083-1102.

${ }_{61}$ Torres Balbás, L., en Historia de España, 725.

62 Aunque se utilizaba en el período taifa, prueba de ello es el zócalo aparecido en las excavaciones en el Patio de la Montería del Alcázar sevillano, seguramente de tiempos de al-Mu'tamid. V. Tabales, M. A., «Investigaciones arqueológicas en el Alcázar de Sevilla», Apuntes del Alcázar de Sevilla 1 (2000), 12-43.

${ }^{63}$ Como el Castillejo de Monteagudo: Torres Balbás, L., «Monteagudo y «El Castillejo» en la Vega de Murcia» Al-Andalus II (1934) 29-36; Navarro Palazón, J., y Jiménez, P., "Arquitectura mardanisí», La arquitectura del Islam occidental, Madrid, 1995; Navarro Palazón, J., Jiménez, P., «El castillejo de Monteagudo: Qașr $\mathrm{Ibn} \mathrm{Sa}{ }^{\mathrm{c} d}$ », Casas y Palacios de Al-Andalus, Madrid, 1995, 63-103. También, la Chanca: R (sin datos del autor), «Restos de una casa árabe en Almería», Al-Andalus X (1945), 170-177. Fuera de España, en Marrue- 
ciones arqueológicas que tienen lugar en arrabales de casas, ya sea en la zona levantina o andaluza ${ }^{64}$, con excepcionales hallazgos palaciales como el de Dār al-Sugrā, en el convento de Santa Clara de Murcia ${ }^{65}$. Sus características son muy semejantes: todas las paredes se encontraban protegidas por mortero, a veces simplemente coloreada su capa superficial con almagre. En la sala, y a veces, en el patio, centro de distribución de la vivienda, era donde se podían encontrar zócalos decorados, rojo sobre blanco, con entrelazos simples.

Mención especial es necesario hacer de las pinturas murales nazaríes, por varias razones. La primera de ellas es que la Alhambra y demás casas granadinas son en los únicos monumentos islámicos, exceptuando Madīnat al-Zahrā', ya comentado, en que ha llegado hasta nosotros pintura mural in situ cuya localización no es exclusivamente la de los zócalos. Podemos observar pintura mural recubriendo paramentos y bóvedas exteriores, donde se fingen materiales arquitectóni-

cos, el palacio de Yūsuf en Marrakech: Meunié, J., Terrasse, H., Deverdun, G., Recherches archéologiques à Marrakech, París, 1952 y casi toda la decoración de la Kutubiyya: Basset, H., Terrasse, H., Sanctuaires et forteresses almohades, París, 1932.

${ }^{64}$ En Valencia: Pascual, J., et alii, 1990, opus cit; Lerma, J., et alii, «Estudio de la vivienda islámica de la ciudad de Valencia», Actas del I Congreso de Arqueología Medieval Española, Huesca, 1985, 448-455; Ramírez López, I., Rodríguez Méndez, C., Conservación y restauración del zócalo islámico de la "costa del castell» de Xátiva, Valencia, 1997; en Murcia: Guillamón Guillamón, B., et alii, «Arquitectura doméstica en la ciudad de Murcia», Murcia musulmana, Murcia, 1989. También Navarro Palazón, J., "Aproximación a la cultura material de Madinat-Mursiya», Murcia musulmana, Murcia, 1989; en Almeria, Acién, M., et alii, «Excavación de un barrio artesanal de Bayyana», Archéologie Islamique 2 (1991), 147-161; en Málaga: Torres Balbás, L., «Hallazgos en la Alcazaba de Málaga», Obra dispersa, 1981, 350-364, Torres Balbás., L. «El barrio de casas de la Alcazaba malagueña», Obra dispersa 1982, 401-409; en Córdoba: Murillo, J., et alii «Intervención arqueológica en el Palacio de Orive», Congreso de Arqueología de Andalucía, vol. III, Sevilla, 1996, 175-187; Murillo, J. et alii, «Aproximación al análisis de los espacios domésticos en la Córdoba Andalusí», Córdoba en la Historia, Córdoba, 1999; en Sevilla: Bosch Vilá, J., Historia de Sevilla: la Sevilla islámica 712-1248, Sevilla, 1984, y varios artículos en El último siglo de la Sevilla islámica, Salamanca, 1994, Jiménez Sancho, A., «Hallazgo de un zócalo pintado», Al-Qantara XX (1999), 377-385; en Huelva: Bazzana, A., «Shaltish (Huelva, Spain), une ville dans les marais» Archéologie Islamique, 4 (1994) 87-116.

${ }^{65}$ Navarro Palazón J., «La Dār aș-Ṣugrà de Murcia. Un palacio andalusí del siglo XII», Colloque International d'Archéologie islamique, El Cairo, 1993, 97-139; Navarro Palazón, J., Jiménez, P., «Casas y Palacios de al-Andalus, s. XII-XIII», Casas y Palacios de Al-Andalus, Madrid, 1995, 17-31, Rallo Gruss, C., Aportaciones a la pintura mural en Castilla, 176-178. En este monumento también apareció decoración pintada en las mucarnas de, presumiblemente, la bóveda. Realizada sobre yeso para restar peso, la pintura es al temple y aplicada en seco. Sin embargo, los restos de zócalos pintados son como los tradicionales, con almagra pintada al fresco sobre mortero de cal y arena. 
cos; la Casa del Partal posee un conjunto pictórico parietal de gran interés, en él se desarrollan escenas de guerreros, tiendas y diversos animales 66 .

La decoración pintada de sus zócalos también difiere del resto de los zócalos islámicos, tanto por su colorido, y sus motivos iconográficos (imitación de ricas telas de seda), como por su técnica de ejecución que, por influencias de aculturación cristiana, presenta una gran parte de su realización a seco ${ }^{67}$. Su influencia se va a dejar sentir en la pintura mural del s. XV de una zona cristiana que se corresponde con el ámbito comercial de la Vía de la Plata.

Paralelamente a la pintura mural islámica, en territorio cristiano, a partir del s. XIII, se han conservado en edificios de cierta calidad (casas señoriales, iglesias rurales) ${ }^{68}$ zócalos muy semejantes. Podemos citar gran número de ellos, situados en la zona de Castilla: Cristo de la Luz y Palacio de Galiana, en Toledo; Sala de los Ajimeces en el Alcázar, Torre de Hércules, Casa Argila, en Segovia; Castillo de Bonilla, en Avila; Castillo de Brihuega, en Guadalajara; Palacio de Tordesillas en Valladolid..., y en Andalucía: Casa Mudéjar de Córdoba, Castillo de Marchenilla, Monasterio de San Isidoro del Campo, Palacio de Mañara de Sevilla, Monasterio de La Rábida en Huelva, Castillo de Rota en Cádiz...

Para estudiar su técnica nos podemos basar en tres vías de conocimiento: la observación directa, la analítica de laboratorio y la documental.

\section{La observación directa (examen organoléptico)}

Pasando revista a los diferentes exámenes realizados con ayuda de nuestros sentidos, lupas y luz rasante, se puede describir lo siguiente:

En cuanto al mortero. En las pinturas «de lo morisco», se han observado varios estratos, en número de uno a cuatro (en el castillo de

${ }^{66}$ Para mayor detalle Rallo Gruss, C., Aportaciones a la pintura mural en Castilla, 184-217.

${ }^{67}$ Esas diferencias de la pintura nazarí respecto al resto de la mural islámica y sus causas fueron expuestas en Rallo Gruss, C., «La técnica de los zócalos nazaríes, accidente o necesidad», Anales de Historia del Arte 8 (1999), 47-66.

68 En realidad no poseemos indicios de viviendas rurales o populares; o no se han conservado o se han transformado según las demandas de uso de cada época. 
Brihuega), sobre muros de piedra (como en el caso de Bonilla de la Sierra), ladrillo (Cristo de la Luz), o adobe (San Isidoro del Campo) ${ }^{69}$. Esos estratos de mortero disminuían de grosor de dentro a afuera, y su color generalmente aclaraba en el mismo sentido. A veces (Cristo de la Luz), el primer estrato del mortero, de color terroso, tenía en su composición pajas. El aspecto de esos morteros era granuloso, con partículas de distintos tamaños y tonos.

En cuanto al diseño. Generalmente geométrico, estaba realizado in situ, sin calco previo. Las huellas grabadas de este diseño se encontraban abundantemente en todas las obras, y no solamente las líneas correspondientes a la pintura, sino todas las líneas del trabajo compositivo, cuadrados, círculos, arcos, líneas divisorias del espacio general, etc. Las líneas de la composición general previa, muchas veces habían sido realizadas con pincel o con cuerda y a color rojo. El resto de las líneas compositivas eran profundas, con bordes vivos, marcadas con un objeto punzante apoyado en un material duro como pudiera ser una regla, distintos cartabones ${ }^{70}$ de madera, con un ángulo fijo y determinado, o diversas formas también de madera ${ }^{71}$. Cuando de círculos o arcos se trataba no resultaba difícil encontrar el punto central del compás.

Después de aplicadas las capas de mortero que se habían considerado necesarias, el alarife «maestro de la geometría», trazaba el dibujo previo o preparatorio ${ }^{72}$, tomando como módulo un submúltiplo de la propia dimensión de la pared a decorar (por ejemplo, plegando tantas veces una cuerda igual a la dimensión total como espacios quisiera obtener).

${ }^{69}$ No en todas las ocasiones ha sido posible comprobar la naturaleza del soporte y los estratos del mortero; solamente cuando la obra presentaba lagunas o bordes al descubierto se han podido observar las zonas interiores.

${ }^{70}$ Nuere, E., «Los cartabones como instrumento exclusivo para el trazado de lacerías», Madrider Mitteillugen, 23 (1982) 372-427, dice: «Uno de los aspectos más interesantes que ofrece al estudio del manuscrito de López de Arenas es el referente al trazado de todos los elementos de la cubierta con el exclusivo auxilio de cartabones». Igual se manifiesta Fernández Puertas, A., «El lazo de ocho occidental o andaluz», Al-Andalus, XL (1975) 199-203.

${ }^{71}$ Isidoro de Sevilla nos habla de instrumentos semejantes utilizados por los artífices medievales en el punto 18 de su libro XIX de las Etimologías, ed. Oroz Reta, J. M.a, 457).

72 Para pintura religiosa, estas operaciones están descritas en Cennino Cennini (1437), Tratado de la pintura, 57-60. 
En principio, compartimentaba el espacio total con la ayuda de cuerdas teñidas con almagra. Dentro de cada espacio, podían obtenerse otros módulos menores por el mismo procedimiento anterior. Así en cada caso el módulo geométrico que nos vamos a encontrar, aun siendo de parecidas proporciones, no se corresponde con los de otras ornamentaciones. Es una composición realizada in situ, con un módulo que va a depender del espacio total de que se disponga (largo de cada paramento, alto del zócalo). A la misma conclusión se llega estudiando la técnica descrita en el Tratado de López de Arenas para carpintería ${ }^{73}$, en donde con sólo los datos del ancho y largo de la estancia a cubrir, permiten la elaboración de toda la armadura. Así no era necesario un dibujo previo para ser traspasado a la pared mediante cartones o calcos ${ }^{74}$, salvo en figuras puntuales al margen del desarrollo geométrico general.

Su técnica de trabajo para dibujar esas tracerías, de rápida y directa ejecución, se nos manifiesta como obra de grandes especialistas, muy habituados a esta clase de trabajos, con un saber hacer artesanal tan desarrollado, que sería casi imposible de emular hoy en día. Como dice Nuere ${ }^{75}$ «... algo aparentemente tan complejo no debió serlo sin embargo en la realidad práctica». La realización de las tracerías ha sido analizada por distintos autores ${ }^{76}$, aunque en relación con las armaduras o los alicatados, a veces desde un punto de vista demasiado

73 Apud Nuere, E., «Los cartabones...», 373; asimismo Nuere, E., en su introducción a Galiay, J., El lazo en el estilo mudéjar, reedición 1992; López de Arenas, D., Carpintería de lo Blanco y tratado de alarifes y relojes, apud Gómez Moreno, M., 1912, 65: «... dar el valor a las partes, y por las partes al todo; y por el contrario por el todo lo que toca a las partes...».

${ }_{74}$ Que habrían dejado en el muro la huella del estarcido o el dibujo grabado con incisión redondeada, marcada a través del papel.

75 Nuere, E, «Los cartabones...», 372.

${ }^{76}$ López de Arenas, D., Carpintería; Lampérez y Romea, V. Historia de la Arquitectura cristiana española en la Edad Media, Madrid, 1930; Galiay y Sarana, J., El lazo; Pavón Maldonado, B., El arte hispano-musulmán en su decoración geométrica, Madrid, 1975; Borrás Gualís, G., «Los materiales, las técnicas artísticas y el sistema de trabajo, como criterios para la definición del arte mudéjar», III Simposio Internacional de Mudejarismo, Teruel, 1986, 317-325; Besteiro Rafales, J., «Aplicación de los grupos de simetría al estudio de ornamentaciones mudéjares aragonesas», II Simposio Internacional de Mudejarismo, Teruel, 1982, 133-142 y «Representaciones simétricas en las lacerías de Aragón», en III Simposio Internacional de Mudejarismo, Teruel, 1986, 459-469; Donaire, A., «El trazado de lacería de ocho en alicatados», III Simposio Internacional de Mudejarismo, Teruel, 1986, 647-663; Isaam el-Said \& Ayse Parman, Geometric Concepts in Islamic Art, Guilford, 1988; Nuere, E., La carpintería de armar, Madrid, 1990; entre otros. 
cerebral ${ }^{77}$, realizando un análisis a posteriori que se descontextualiza de su realidad histórica.

No nos debe chocar que la técnica empleada en la ejecución de la pintura «de lo morisco» sea semejante a la empleada en la realización de alicatados, yeserías o artesonados ${ }^{78}$. Lo importante era la clara relación entre el todo y las partes.

Todo esta composición grabada se habría realizado cuando el mortero estaba fresco, porque de haberse hecho después, la rotura de los bordes de las líneas se hubiera manifestado desigual por desprendimiento de materia.

En cuanto a la pintura. El color predominante era el rojo almagra, que se extendía a modo de cintas que se entrecruzaban formando el diseño geométrico. Los trazos de color, de una misma anchura en cada obra, se cortaban para marcar el entrelazo de una línea a otra, lo que se manifestaba en un pequeño trazo producido por el levantamiento seco del pincel. Este color rojo, exceptuando las zonas muy degradadas por un pésimo estado de conservación, no se diluía en agua, lo que resulta sintomático, ya que los aglutinantes utilizados en aquella época para pintar al temple en su mayoría estaban preparados con colas (que sí se disuelven en agua). Todo ello conduce a pensar que de un fresco se trataba. Hay que destacar que el almagra es un color altamente estable cuando está aplicado con la técnica del fresco.

Por orden de cantidad, el color más utilizado después del rojo era el negro, en composiciones donde siempre complementaba a aquél (Brihuega, Bonilla de la Sierra, Coca, Cuéllar). El azul, de gran calidad, aparecía en motivos pequeños y en obras de gran delicadeza; a veces también se presentaban el verde tierra y el ocre. Todos estos colores están presentes en las pinturas murales andaluzas.

77 Prieto y Vives, A., El arte de la lacería, recopilación de varios artículos del autor, Madrid, 1977 (varios artículos del autor escritos entre 1932 y 1935).

78 Nuere, E., «Los cartabones...», 382 y ss., dedica un capítulo a «los cartabones de lacería en su uso general», donde apunta que «ello autoriza a suponer que serían empleados por cualquier tracista, tanto en alicatados como en yeserías». Aunque no menciona la pintura, el proceso sería el mismo, incluso muchas veces realizado por los mismos artesanos. 


\section{La analítica de laboratorio}

Como se ha dicho, se realizaron análisis de muestras en las instalaciones de la Universidad de Alfonso $\mathrm{X}^{79}$, cuyos resultados ya se han ido mencionando.

\section{Recopilación de documentación}

Existe muy poca documentación de datación medieval, más escasa aún si nos ceñimos al tema de la pintura mural, y dentro de ella a la hispano-musulmana, ya de territorio cristiano como islámico. Sin embargo, hay un documento, tardío en el tiempo, pero que recoge toda esas características de la pintura estudio de este artículo. Se trata de unas Ordenanzas, en donde el artífice creador de este tipo de decoración es citado como "pintor de lo morisco» ${ }^{80}$.

Dice así: «Hordenanzas de pintores de Córdoba (1493)... Si lo examinare en el arte de lo morisco sea sabido... si labra bien al fresco e si sabe aparejar e dorar en cubos e en racimos e en copas e que pertenece a lo morisco e si esto se fallare que lo sabe que lo ayan por maestro e si no se fallare maestro en todo o en las cosas principales dello que non lo ayan por maestro e que sea obrero fasta que aprenda... Esto quanto a la pyntura de lo morisco e quanto a la pyntura de los aliceres que se pinten al fresco. /Primeramente ordenamos e mandamos que por cuanto en esta pintura non puede aber engaño porque se pynta con colores muy bajas como acofaira e almagra e prieto e porque estas resciben la cal en si templadas con agua e albayalde para esta obra facer de cal... para esta obra facer de cal porque esta tal permanece e seyendo desto otro morisca e tornase negro si en lugar de bermellon se pone azarcon pero si algun azul fino o verde cardenillo obieren de poner dejen secar la cal e verde aboli e lo azul que lo den con templa de huevos».

${ }^{79}$ A la cual agradezco el permitirme efectuar estos análisis, en especial al doctor en química Enrique Parra Crego.

80 En el folio 82 del Tomo I, Archivo del Ayuntamiento de Córdoba. Comentadas en los artículos: Ramírez de Arellano, R., «Ordenanzas de pintores de 1493 y 1543», Boletín de la R.A. de BBAA, IX (1915), 26-46; Rallo Gruss, C., «Aportaciones de un texto en el Boletín de la Academia a la pintura mudéjar», Academia, 87 (1998), 241-284. 
Como vemos, concuerda con todo lo dicho sobre la técnica de la pintura al fresco. Además de citar esa denominación expresamente, nos habla de colores a utilizar: acofaira (ocre), almagre, prieto (negro), bermellón; y los que son no recomendables: el azarcon, porque (en la técnica del fresco) se vuelve negro; y que si se han de aplicar los colores verde y azul se pongan cuando la cal esté seca empleando como aglutinante el temple de huevos ${ }^{81}$.

En resumen, esa pintura hispano-musulmana, ya en territorio islámico o en zona cristiana, se define por una serie de características comunes, además de la técnica de ejecución ya mencionada:

1. Su paleta limitada respecto al uso del color generalmente es monocroma, realizándose el diseño en color rojo almagre sobre el tono blanco sucio del mortero, o a veces, menos frecuentemente, al revés. Los colores se presentan tal cual, sin permitir la introducción de luces y sombras, sin trasparencias ni perspectivas, para lograr una estricta planitud, con carácter atectónico. Esto le va a conferir una sensación de aplomo, equilibrio y reposo. Mucho se podría decir acerca del color rojo y su aspecto simbólico del poder en la Edad Media ${ }^{82}$, aunque simplemente aquí es utilizado por dos razones, por la fácil localización y economía del pigmento almagre empleado, y por la gran fuerza que tiene ese color frente al «quasi-blanco» del fondo para lograr el efecto final pretendido.

2. Su diseño es disciplinarmente geométrico ${ }^{83}$, frecuentemente de entrelazos y composición centralizada en estrellas de diferente número de puntas, todo ello enmarcado y delimitado perfectamente en sus bordes ${ }^{84}$. Ante el aspecto final de una pintura de este tipo se comprende su perfecta definición al denominarla como «echar cintas» en

${ }^{81} \mathrm{El}$ autor de estas Ordenanzas conocía perfectamente la técnica, todas sus recomendaciones son muy acertadas.

82 Ver González Arce, J. D., «El color como atributo del poder», Cuadernos de Arte e Iconografia, VI (1993), 103-108. En Chevalier, J., et alii, Diccionario de simbolos, Barcelona, 1986, 320, se dice: «Para Rümi igualmente el rojo y el verde simbolizan la gracia divina y llevan al alma el mensaje de la esperanza... El rojo proviene del sol y es en este sentido el mejor de los colores».

${ }^{83}$ En parte debido a facilitar su ejecución a la mano del alarife o maestro albañil, no de un pintor.

84 Este espacio compuesto con una figura central de número «mágico», viene determinada por su ascendencia islámica y el valor divino del número en esta cultura, según Massignon, L., «Los métodos de realización artística de los pueblos del Islam», Revista de Occidente, 38 (1932), 255-277. 
varios contratos ${ }^{85}$. Cuando no se trata de cintas que se entrelazan y cruzan formando dibujos simétricos respecto a un eje que compartimenta el muro en espacios iguales, nos encontramos con un motivo geométrico o uno floral estilizado, casi abstracto, que se repite en número indefinido, constituyendo únicamente un fondo textil ${ }^{86}$.

3. Ese diseño se podría definir con las palabras de profusión y repetición, ya que los motivos, como caracteriza a la ornamentación musulmana, se repiten aparentemente con gran exuberancia e invadiendo el espacio. Respecto a la repetición, hay que matizar que el artista juega con una serie de motivos iguales, pero en combinaciones siempre distintas; cuando se observa cualquier decoración de una determinada sala, se puede describir como un conjunto de diferentes propuestas para resolver espacios iguales con elementos semejantes.

En cuanto a la profusión, la decoración islámica y «de lo morisco» se extiende por todo el espacio de la zona de zócalos, produciendo a veces la sensación de «horror vacui»» ${ }^{87}$, de «ardor decorativo» ${ }^{88}$ para conseguir el «efecto inmaterial de un edificio»" ${ }^{89}$, pero este espacio está previamente delimitado, marcando la frontera entre la parte decorada y la vacía del paramento. Lampérez matiza que «adolece de sequedad y monotonía» ${ }^{90}$, aunque reconoce que «no roban (esa sequedad y monotonía) su indiscutible belleza, por la inagotable fantasía con que están combinados los motivos en el difícil problema de llenar extensas superficies y por la brillantez que le presta una potente decoración» ${ }^{91}$.

4. Lejos de ser seca y monótona, es una decoración de gran expresividad, carácter que le confiere tanto su color brillante, como el efecto que produce la yuxtaposición de luz y tinieblas, de claros y oscuros, en la luz ambiental de las salas y en la misma organización del

85 Domínguez Casas, R., Arte y etiqueta de los Reyes Católicos, Madrid, 1993, 181, de AGS CMC, 1. época. leg 87. Sin foliar. Córdoba, 20 de marzo de 1483. 267.

86 "un fondo para el pensamiento», como dice Massignon, L., «Los métodos...»,

${ }^{87}$ Grabar, O., La formación, 23, dice: «... aversión del arte islámico hacia las superficies vacías, no se trata tanto de un "horror vacui" como de un intento consciente de dar significado a toda la superficie decorativa, de una concepción globalizadora de ésta».

88 Martínez Caviró, B., Mudéjar toledano. Palacios y conventos, Madrid, 1980, 17.

89 Pérez Higuera, T., Arquitectura mudéjar en Castilla y León, Valladolid, 1994, 77.

90 Lampérez y Romea, V., Historia de la Arquitectura cristiana española en la Edad Media, Madrid, 1930, 529.

${ }^{91}$ Ibid., 531. 
espacio. Respecto de la luz, el gran contraste que marca entre línea y fondo logra una diferenciación clara entre la zona decorada y la vacía, imposible de obtener con paredes cubiertas con mármoles, tapices o azulejos. Es decir, crea un ambiente característico y peculiar. Respecto al espacio, compartimentado y «deliberadamente ofuscante» como dice Chueca, su organización mediante la pintura «de lo morisco» logra el efecto de una gran celosía que rompe cualquier impresión de punto de fuga, y constituye un espacio yuxtapuesto al propio espacio del muro, una pantalla arquitectónica, una estratificación sucesiva, como advertía Chueca que ocurría con la disposición arquitectónica de la Alhambra ${ }^{92}$.

¿Cómo se ha logrado este efecto? Mediante el expresivismo de la monocromía, de la geometrización y del fraccionamiento del espacio mural obtenido por su decoración.

Así, como dice Borrás, por medio de la ornamentación que invade el espacio, se conseguiría la «disolución óptica e ilusoria de la tectónica mural» ${ }^{93}$.

Una vez analizadas las características de la pintura mural hispano-musulmana, la del período romano, y aún la existente en la Península anterior a la romanización, podemos concluir que en esa pintura mural al fresco hispano-musulmana se produce la perduración de la técnica romana, que podríamos considerar como tradicional hispana. No hay que buscar influencias foráneas ni dispersar nuestra atención hacia técnicas practicadas en la pintura mural de zonas tan alejadas como pueda ser Egipto ${ }^{94}$ : la técnica de la pintura al fresco fue asimilada por los musulmanes invasores desde la pintura hispano-romana como una manera de trabajo tradicional del país, y transmitida a la pintura «de lo morisco» realizada en la Castilla cristiana hasta los finales de la Edad Media.

\footnotetext{
92 Chueca Goitia, F., Invariantes castizos de la arquitectura española, Madrid, 1947, 37 : «En el palacio nazarí nos encontramos con la estratificación sucesiva, degradada desde el espectador hasta el fondo, de pantallas planas más o menos porosas; está producido por saltos de espacio»".

${ }_{93}$ Borrás Gualís, G., Arte mudéjar aragonés, Zaragoza, 1978, 88

94 Como se desprende del estudio realizado por García Bueno, A., Medina Flórez, V., «Algunos datos...», Al-Qantara, XXIII (2002), 216.
} 


\title{
RESUMEN
}

El convencimiento de que a finales de la Edad Media las paredes eran decoradas con pintura al seco, realizada con temple, más o menos graso, olvidando la técnica de pintura al fresco utilizada habitualmente por los romanos, es algo admitido para toda la Europa Occidental. Textos como el Libro dell'Arte de Cennino Cennini nos hablan de su recuperación por los iniciadores del Renacimiento italiano como el Giotto; desde allí se expandirá la técnica a todos los países europeos.

Sin embargo, en los monumentos hispanos con iconografía de tradición islámica se siguen realizando decoraciones al fresco hasta el siglo XV. En busca de explicaciones a esta excepción, en este artículo se buscan las fuentes de esa tradición técnica, analizando ejemplos de pintura mural ibera, romana, islámica y «de lo morisco» o mudéjar. El estudio se centra en los materiales utilizados, incluso con analítica de laboratorio, en paralelo con los motivos estilísticos que se encuentran en cada época.

\begin{abstract}
It is generally thought that in Western Europe and at the end of the medieval period, tempera paint with oil as a medium was applied to dry plaster walls because the Roman technique for painting on wet plaster (al fresco) had been forgotten. Texts such as the Libro dell'Arte by Cennino Cennini discuss the recovery of the fresco technique by some of the founding painters of the Italian Renaissance, such as Giotto. From Renaissance Italy, it is argued, the technique expanded to the rest of Europe. However, in medieval Hispanic monuments with Islamic iconography there is evidence of painted fresco decoration dated prior to the fifteenth century. This paper studies the sources of this technical tradition by analysing examples of Iberian, Roman, Islamic, Mudéjar and Morisco mural painting.
\end{abstract}

